\title{
INVERTEBRATE ICHNOFOSSILS FROM THE ADAMANTINA FORMATION (BAURU BASIN, LATE CRETACEOUS), BRAZIL
}

\author{
ANTONIO CARLOS SEQUEIRA FERNANDES \\ Departamento de Geologia e Paleontologia, Museu Nacional, UFRJ, Quinta da Boa Vista, São Cristóvão, 20940-040, \\ Rio de Janeiro, RJ, Brazil.fernande@acd.ufrj.br \\ ISMAR DE SOUZA CARVALHO \\ Departamento de Geologia, Instituto de Geociências, UFRJ, 21949-900, Cidade Universitária, Rio de Janeiro, RJ, \\ Brazil.ismar@geologia.ufrj.br
}

\begin{abstract}
The Bauru Group is a sequence at least $300 \mathrm{~m}$ in thickness, of Cretaceous age (TuronianMaastrichtian), located in southeastern Brazil (Bauru Basin), and consists of three formations, namely Adamantina, Uberaba and Marília. Throughout the Upper Cretaceous, there was an alternation between severely hot dry and rainy seasons, and a diverse fauna and flora was established in the basin. The ichnofossils studied were found in the Adamantina Formation outcrops and were identified as Arenicolites isp., ?Macanopsis isp., Palaeophycus heberti and Taenidium barretti, which reveal the burrowing behavior of the endobenthic invertebrates. There are also other biogenic structures such as plant root traces, coprolites and vertebrate fossil egg nests. The Adamantina Formation (Turonian-Santonian) is a sequence of fine sandstones, mudstones, siltstones and muddy sandstones, whose sediments are interpreted as deposited in exposed channel-bars and floodplains associated areas of braided fluvial environments.
\end{abstract}

Key words: Bauru Basin, ichnofossils, late Cretaceous, continental palaeoenvironments, Adamantina Formation.

RESUMO - O Grupo Bauru é uma seqüência de pelo menos 300 m de espessura, de idade cretácica (TuronianoMaastrichtiano), localizada no Sudeste do Brasil (bacia Bauru), e consiste das formações Adamantina, Uberaba e Marília. Durante o Cretáceo Superior houve uma alternância entre estações extremamente quentes e secas e estações chuvosas, com uma fauna e uma flora diversificada que se estabeleceu na bacia. Os icnofósseis estudados são oriundos dos sedimentos da Formação Adamantina, sendo identificados como Arenicolites isp., ?Macanopsis isp., Palaeophycus heberti e Taenidium barretti, os quais representam comportamento escavador de invertebrados endobentônicos. Ocorrem também outras estruturas biogênicas, tais como traços de raízes de plantas, coprólitos e ninhos fossilizados de vertebrados. A Formação Adamantina (Turoniano-Santoniano) é uma seqüência de arenitos finos, argilitos, siltitos e arenitos argilosos interpretados como depositados em barras expostas e em planícies de inundação em ambientes fluviais entrelaçados.

Palavras-chave: Bacia Bauru, icnofósseis, Cretáceo superior, paleoambientes continentais, Formação Adamantina.

\section{INTRODUCTION}

The Bauru Basin have been widely studied, specially by its fossil content, which is composed of charophyte oogonia algae, pteridophyte sporocarpes (Marsiliaceae), coniferophyte logs, ostracods, gastropods, bivalves, invertebrate and vertebrate ichnofossils occur as well as diversified vertebrate fauna of fishes, amphibians, reptiles (lizards, ophidians, turtles, crocodylomorphs, dinosaurs) and mammals (e.g., Bertini, 1993; Castro et al., 1999; Ribeiro \& Ribeiro, 1999; Musacchio, 2000). Crocodilomorphs, eggs and dinosaurs compound the fossil record of the Adamantina Formation. Recent studies in continental deposits of the
Adamantina Formation revealed the presence of an invertebrate ichnofauna composed of unornamented U-tubes, empty subcylindrical burrows and sinuous meniscated tubes. The aim of this paper is to characterize this invertebrate ichnofauna and to discuss its palaeoecological and palaeoenviromental significance.

\section{GEOLOGICAL SETTING}

The Bauru Basin had its origin during the opening of the South Atlantic ocean, through thermo-mechanical subsidence processes (Fernandes \& Coimbra, 1996). This inland basin, located in southeastern Brazil, has an area of $370,000 \mathrm{~km}^{2}$ 


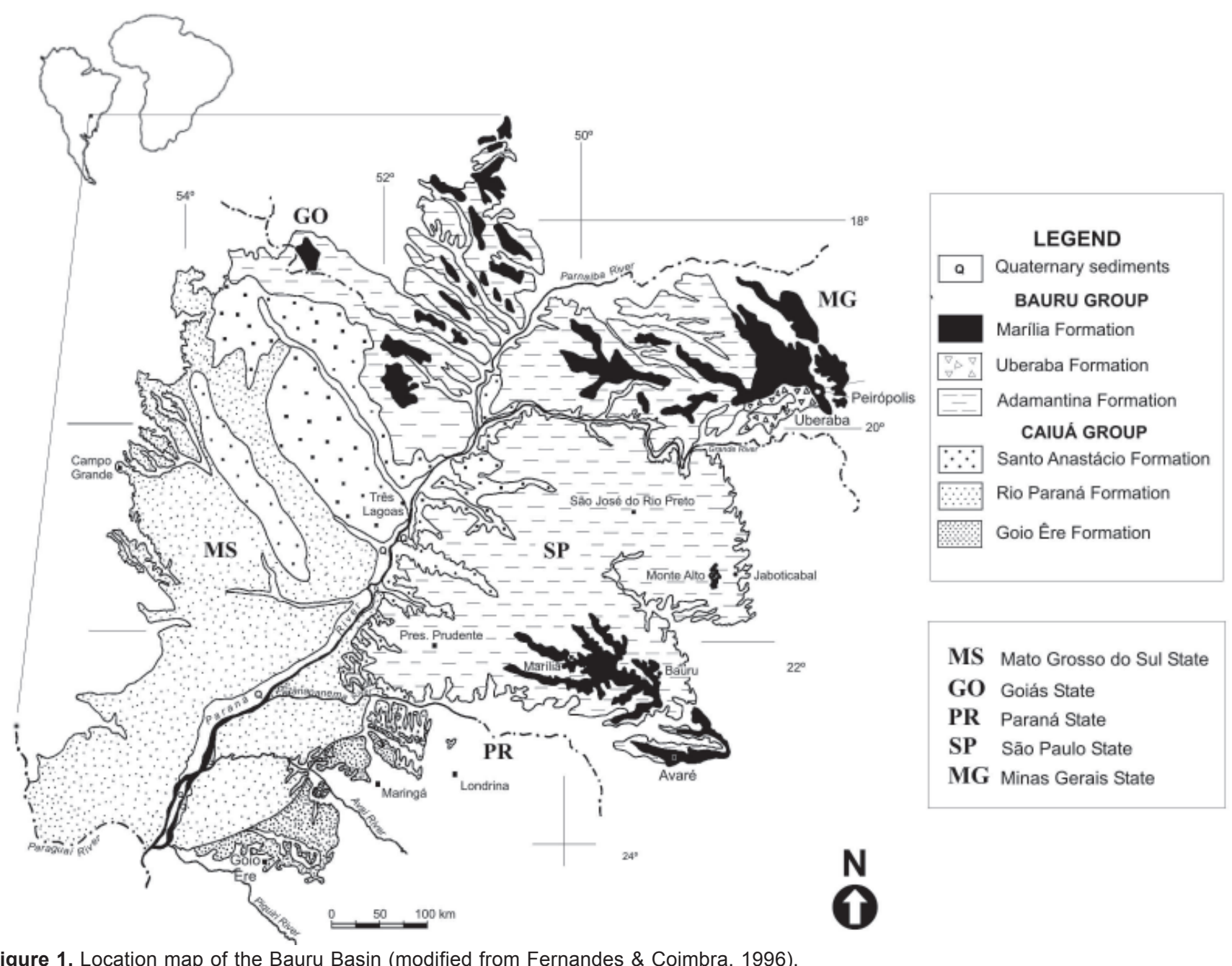

Figure 1. Location map of the Bauru Basin (modified from Fernandes \& Coimbra, 1996).

(Figure 1) comprising a Cretaceous sequence (Figure 2), with at least $300 \mathrm{~m}$ of siliciclastic sediments (Fulfaro et al., 1994; Fernandes \& Coimbra, 1996, 1999). The age of the Bauru Basin ranges from Aptian to Maastrichtian (Fulfaro et al., 1994) and the sediments are generally included into the Caiuá and Bauru groups.

The Bauru Group was divided by Fernandes \& Coimbra (1996) into three formations, namely Adamantina, Uberaba and Marília. The Adamantina Formation (Turonian-Santonian age, Castro et al.,1999; Dias-Brito et al., 2001) is a sequence of fine-grained sandstones intercalated by mudstones, siltstones and muddy sandstones. The lowermost part of this unit was redefined by Batezelli et al. (1999) as the Araçatuba Formation. The Uberaba Formation (ConiacianCampanian, Goldberg \& Garcia, 2000) is composed of finegrained green sandstones interbedded by siltstones, coarse sandstones, mudstones and volcaniclastics. The Marília Formation (Maastrichtian, Dias-Brito et al., 2001) was formally proposed by Soares et al. (1980) as a succession of coarse to conglomeratic sandstones, mudstones and carbonate beds.

Throughout the Late Cretaceous, there was an alternation between severely dry and hot rainy seasons, and a diverse fauna and flora was established in the basin. Plant root traces, invertebrate burrows and vertebrate coprolites and egg nests are found in the Bauru Basin deposits. They occur in distinct stratigraphic levels generally in fine-grained sandstones.

\section{SEDIMENTARY FACIES}

The ichnofossils discussed in this paper occur in finegrained sandstones of the Adamantina Formation deposited during sudden floods on alluvial plains under a dry and hot season. They were collected from three localities SW of São Paulo State (Figure 3). The locality A is exposed at km 595 in SP-294 road, municipality of Adamantina. The local succession (Figure 4A) is $1.3 \mathrm{~m}$ thick and consists of fine-grained sandstones with climbing ripples. The locality B occurs in the SP-463 road, $1 \mathrm{~km}$ from the crossing with the SP-320 road nearby the city of Jales, municipality of Jales. The deposits (Figure 4B) are $7.0 \mathrm{~m}$ thick and consist of a succession of fine-grained sandstones intercalated with coarse-grained sandstones and thinner levels of mudstones. Climbing ripples are present in the fine-grained sandstones, along with ostracods and theropod teeth remains. The locality $\mathrm{C}$ crops out at Fazenda São José, in Prudêncio e Morais district, municipality of General Salgado. The outcrop (Figure 4C) comprises a $6.0 \mathrm{~m}$ thick succession of coarse-grained sandstones with trough cross-stratification intercalated with 


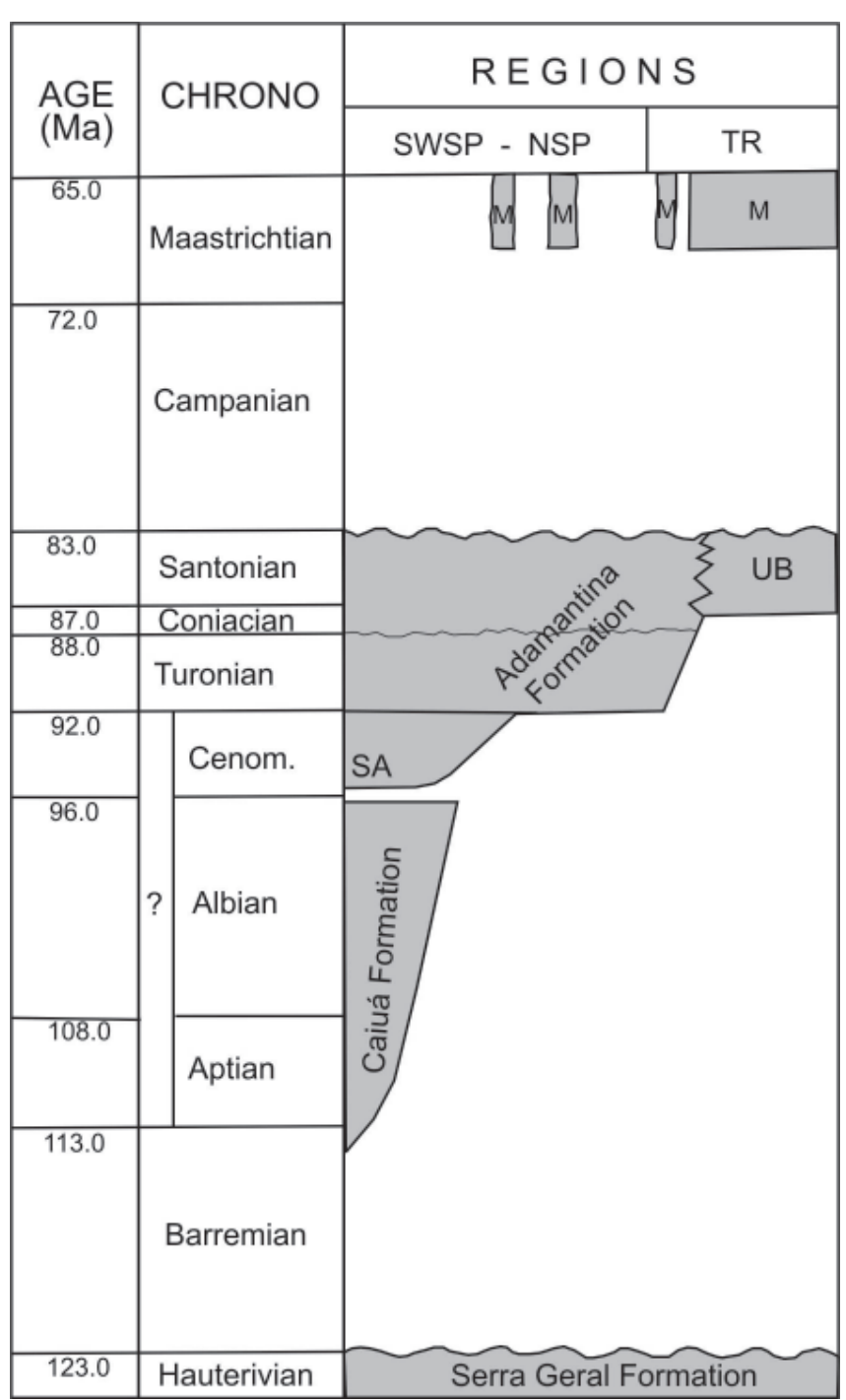

Figure 2. Diagramatic stratigraphic chart of the Bauru Basin Abbreviations: SWSP, Southwest of São Paulo State; NSP, North of the São Paulo State; TR, Triângulo Mineiro region; M, Marília Formation; SA, Santo Anastácio Formation; UB, Uberaba Formation (modified from Dias-Brito et al., 2001).

fine-grained sandstones with planar cross-stratification, muddy siltstone, and a caliche horizon at the lower part of the sequence. Vertebrate bones occur in the fine-grained sandstones.

Collected specimens are housed in the collection of the Departamento de Geologia, Instituto de Geociências, Universidade Federal do Rio de Janeiro (UFRJ-DG).

\section{SYSTEMATIC ICHNOLOGY}

Ichnogenus Arenicolites Salter, 1857 Arenicolites isp.

(Figure 5)

Material. UFRJ-DG 203-Ic, several specimens recorded in the field and one slab with nine specimens. Associated in the same slab there are Taenidium specimens.

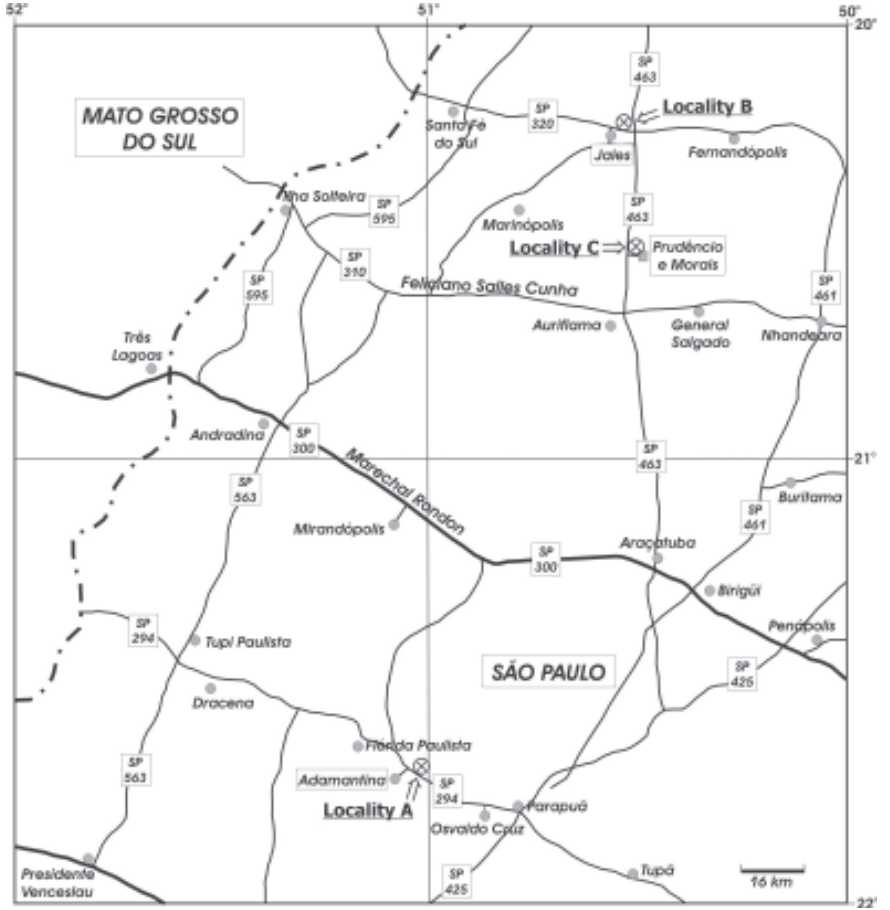

Figure 3. Location map of the invertebrate ichnofossil localities of the Adamantina Formation in São Paulo State.

Collecting site. Locality A.

Description. Simple, unornamented U-tubes without spreite, perpendicular to beds, with some specimens reaching $10 \mathrm{~cm}$ down in the substrate. When observed in the bedding planes (Figure 5A), they are seen as paired circular structures with variable diameters between 8-10 $\mathrm{mm}$. In the Figure 5B, a vertical cross section through the paired circular structures (although the lowermost portion is broken) shows the connection as a U-tube, without linning.

Remarks. Arenicolites is interpreted as a dwelling burrow of suspension feeders in marine environments (Fillion \& Pickerill, 1990) and by oligochaete worms (Bromley \& Asgaard, 1979) or insects (Rindsberg \& Kopaska-Merkel, 2005) in continental environments. Rindsberg \& KopaskaMerkel (2005) revised and analysed the four ichnospecies of Arenicolites: A. carbonarius (Binney, 1852), A. sparsus Salter, 1856, A. curvatus Goldring, 1962 and A. longistriatus Rindsberg \& Kopaska-Merkel, 2005. The studied sample illustrated in the Figure 5B resembles the diagnostic characteristic of $A$. sparsus as a simple, regular U-shaped burrow with vertical limbs and lacking a thick lining (Rindsberg \& Kopaska-Merkel, 2005). Therefore, the preservation of the specimen UFRJ-DG 203-Ic does not allow an accurate identification of this ichnospecies. Arenicolites is known only from three Brazilian Mesozoic continental lithostratigraphical units: Sanga do Cabral and Caturrita formations (Triassic of the Paraná Basin; Gandini et al., 2004; Netto, 1989, 2000; Netto et al., 1994), and Sousa Formation (Lower Cretaceous of the Sousa Basin; Carvalho, 1989). 

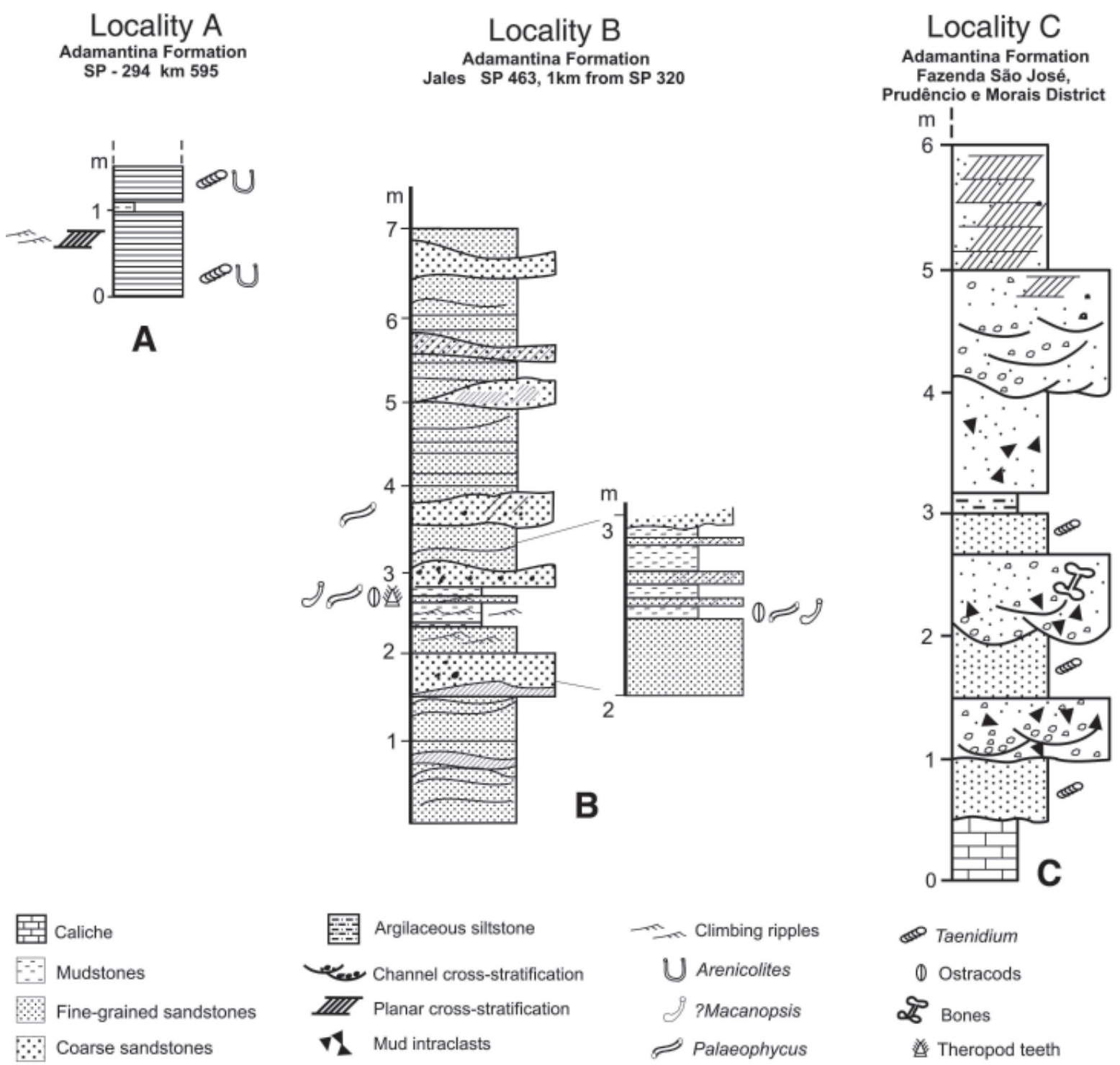

Figure 4. Stratigraphic sections of the localities: A, the $1.3 \mathrm{~m}$ thick sequence of the locality $\mathrm{A}$. Fine-grained sandstones with tubes of Arenicolites are intercalated with a thin mudstone level. B, in the locality B, the deposits consist of fine-grained sandstones intercalated with coarse-grained sandstones and mudstones. The bioturbation occurs in the fine-grained sandstone, whereas the ostracods and theropod teeth are present in the mudstone levels. $\mathbf{C}$, the $6.0 \mathrm{~m}$ thick deposits of the locality $\mathrm{C}$ consist of coarse-grained sandstones with channel cross-stratification and vertebrate bones and eggs. These horizons are intercalated with fine-grained sandstones with Taenidium burrows and mudstone levels. The $0.5 \mathrm{~m}$ thick layer of caliche is restricted to the base of the section.

\section{Ichnogenus Macanopsis MacSotay, 1967}

?Macanopsis isp.

(Figure 6)

Material. UFRJ-DG 190-Ic, one specimen.

Collecting site. Locality B.

Description. Vertical, curved, unbranched, empty subcylindrical burrows, with a hemispherical hollow extremity. The specimen has a continuous diameter of $10 \mathrm{~mm}$, with a bend of $90^{\circ}$ before the hemispherical hollow which has a diameter of $15 \mathrm{~mm}$.

Remarks. Though the type materials of Macanopsis described by Macsotay (1967) are certainly marine (Bown \& Kraus, 1983), it was also recorded in the fluvial floodplain deposits of the lower Eocene Willwood Formation (Bown \& Kraus, 1983; Hasiotis et al., 1993). Similar structures were recorded in Oligocene point bar deposits of the nearshore fluvial Jebel Qatrani Formation in Egypt (Bown, 1982). They were interpreted as a dwelling trace of insects or spiders (Bown \& Kraus, 1983). Macanopsis-like burrows in Holocene sediments are attributed to a variety of invertebrates including insects, spiders, decapods and mollusks (see Bown \& Kraus, 1983 to references). There are known two ichnospecies of Macanopsis, M. pagueyi Macsotay, 1967 and M. astreptum Bown \& Kraus, 1983. The Brazilian specimen described herein has a characteristic similar to M. plagueyi that is the curve of the burrow in the confluence with the bulbous termination, which is vertical tubular in M. astreptum. Macanopsis is 

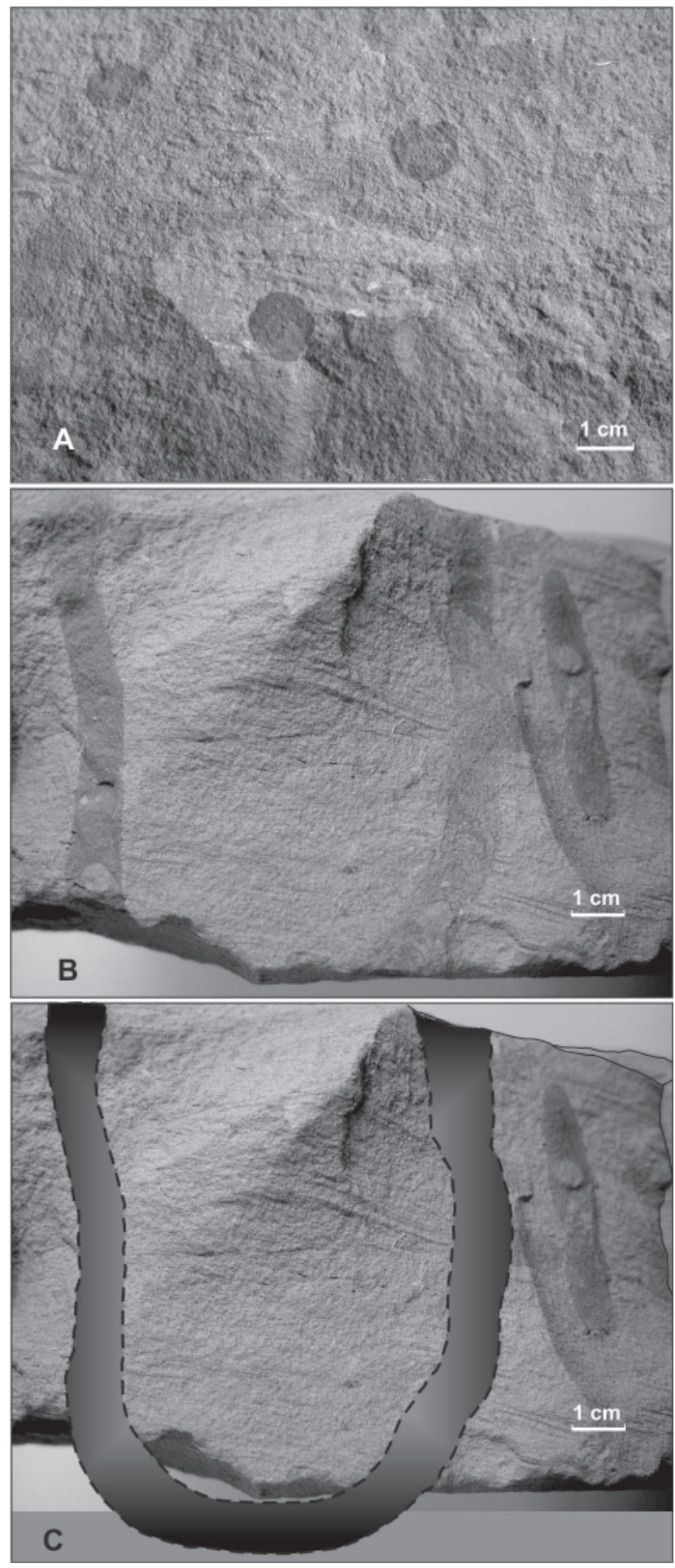

Figure 5. Arenicolites isp. UFRJ-DG 203 Ic: A, paired circular structures observed in the bedding plane; $\mathbf{B}$, vertical cross section where is observed the vertical limbs of the U-tube; $\mathbf{C}$, hypothetical reconstruction of the $U$-tube shown in the picture $B$.

known from lower Tertiary deposits (Macsotay, 1967; Häntzschel, 1975; Bown \& Kraus, 1983), but it was also recorded in the Cretaceous sediments of the Marilia Formation of the Bauru Group (Fernandes, 2001; Fernandes et al., 2002). Its presence in the sediments of the Bauru Basin comprises the only known occurrences of this ichnogenus in Brazil.

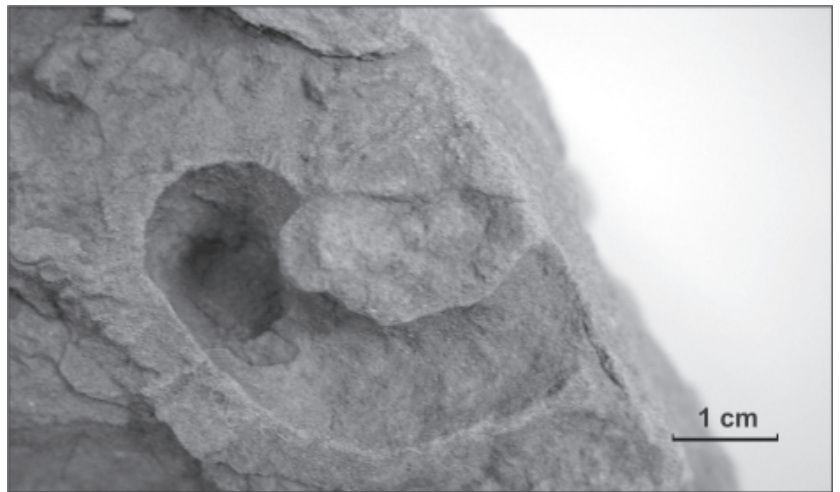

Figure 6. ?Macanopsis isp., UFRJ-DG 190 lc, showing the empty subcylindrical burrow with a hemispherical hollow extremity.

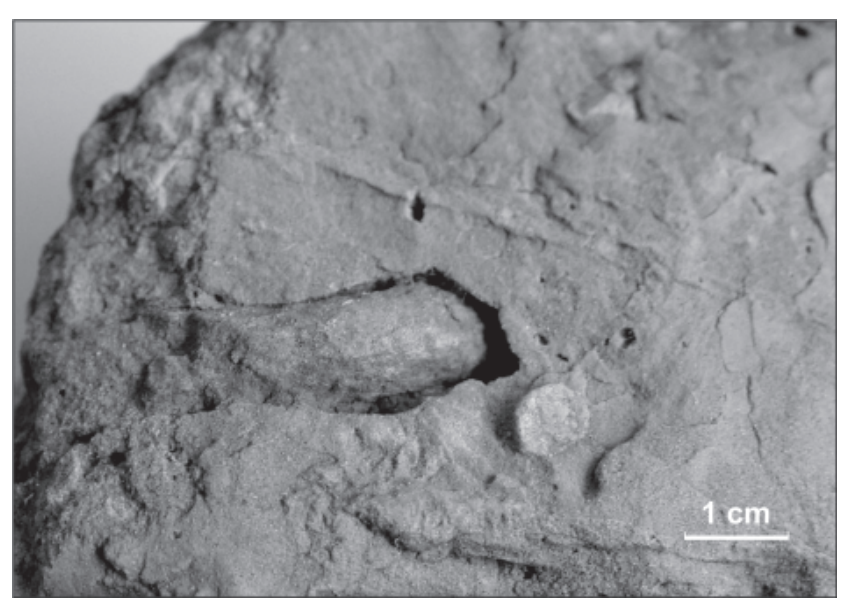

Figure 7. Palaeophycus heberti, UFRJ-DG 189 Ic, characterized by the unbranched, smooth, slightly curved and cylindrical burrow.

\section{Ichnogenus Palaeophycus Hall, 1847 Palaeophycus heberti (Saporta, 1872)}

(Figure 7)

Material. UFRJ-DG 189-Ic, a slab with one specimen.

Collecting site. Locality B.

Description. Unbranched, smooth, slightly curved, cylindrical burrow, with diameter between $1.0 \mathrm{~cm}$ and $1.5 \mathrm{~cm}$. Burrow fill identical to the host rock. The specimen shows a thick space between the burrow fill and the host rock. Preserved as endichnia.

Remarks. There are five recognized ichnospecies of Palaeophycus: P. tubularis Hall, 1847, P. striatus Hall, 1852, P. heberti (Saporta, 1872), P. sulcatus (Miller \& Dyer, 1878) and P. alternatus Pemberton \& Frey, 1982. P. tubularis and $P$. heberti are comprised by smooth and unornamented straight to slight curved burrows. P. tubularis is thinly lined, and $P$. heberti is composed by thick-lined cylindrical burrows (Pemberton \& Frey, 1982), a feature recognized in the studied specimen. Palaeophycus is considered a dwelling burrow constructed by a predaceous or suspension-feeding animal (Pemberton \& Frey, 1982), 
produced in marine environments probably by polychaetes. In nonmarine environments, it is probably produced by insects and other arthropods (Buatois \& Mángano, 1993), ranging in age from Precambrian to Holocene (Pemberton \& Frey, 1982). The occurrence of $P$. heberti in the Adamantina Formation is the first record of this ichnospecies in the Cretaceous non-marine sediments of the South America. In continental Mesozoic stratigraphic units of Brazil, Palaeophycus isp. was only identified in the Cariri Formation, Lower Cretaceous, Araripe Basin (Fernandes et al., 2002).

Ichnogenus Taenidium Heer, 1877

Taenidium barretti (Bradshaw, 1981)

(Figure 8)

Material. UFRJ-DG 262-Ic to 274-Ic, Several specimens recorded in the field and 17 slabs with 38 specimens.

Collecting site. Localities A and C.

Description. Sinuous and cylindrical unwalled burrows with distinct back-fill containing alternations of meniscusshaped packets of sediment. The menisci are thin and strongly curved, variably-spaced. The traces have variable diameter from 1.0 to $2.0 \mathrm{~cm}$, which is apparently constant in each specimen, and with variable preserved length, up to $22.0 \mathrm{~cm}$.

Remarks. Taenidium barretti differs from other ichnospecies of Taenidium by its more curved and thin menisci, and its variable diameter and more sinuous burrows. Probably produced by insect larvae or other arthropods with an exoskeleton in non-marine sediments, the ichnogenus Taenidium has a distribution from the Lower Cambrian to probably the Quaternary (Uchman, 1995), being a common component of the Cruziana Ichnofacies in the marine realm, and a typical component of the Scoyenia Ichnofacies, in non-marine settings (Buatois et al., 2002). Taenidium barretti has been recorded mainly from non marine environments (Keighley \& Pickerill, 1994), such as the Lower Cretaceous Wealden Group of southern England (Goldring \& Pollard, 1995) and Cretaceous/Tertiary beds of Central Utah, USA (Bracken $\&$ Picard, 1984). This is the first occurrence of Taenidium barretti in Brazilian Cretaceous deposits.

Taenidium is the most common continental invertebrate ichnofossil registered in Brazilian Mesozoic stratigraphic units. In Paraná Basin, the Triassic sediments of the Sanga do Cabral Formation contain Taenidium serpentinum Heer, 1877 (Netto et al., 1994), wich also occurs in the aeolian sediments of the Botucatu Formation (Lower Cretaceous), as well as Taenidium satanassi D'Alessandro \& Bromley, 1987 (Fernandes et al., 1990).

Taenidium isp. was recorded in the Lower Cretaceous deposits of the Arajara Formation (Araripe Basin, Fernandes et al., 1998; Carvalho, 1989), and in the Antenor Navarro and Sousa formations (Sousa Basin, Fernandes \& Carvalho, 2001)Arenicolites and Taenidium are reported in association from the Sanga do Cabral Formation.
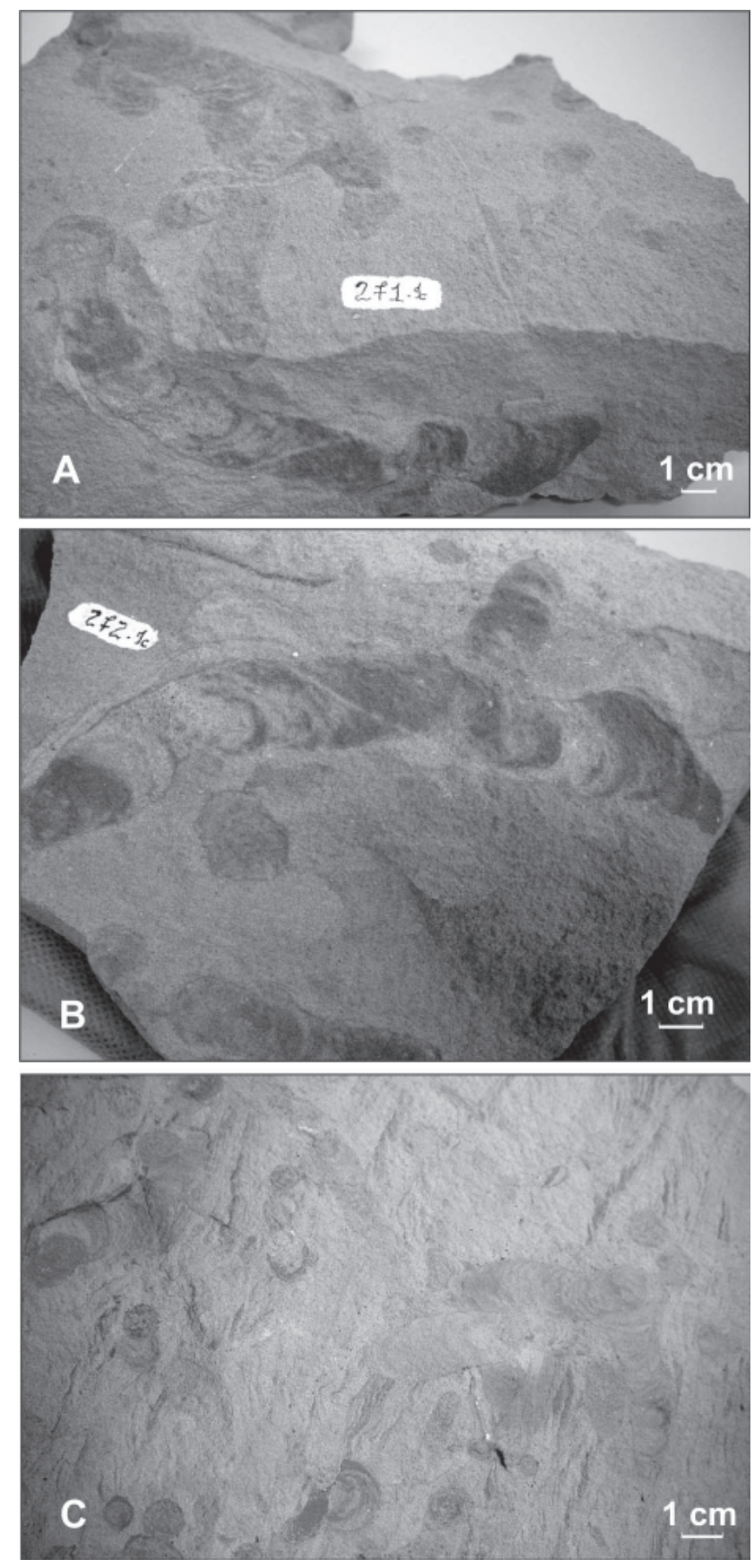

Figure 8. Taenidium barretti. A, UFRJ DG-271 Ic; B-C, UFRJ-DG 272 Ic. Both samples show the sinuous and cylindrical unwalled burrows with thin and strongly curved menisci.

\section{OTHER FOSSIL REMAINS FROM THE ADAMANTINA FORMATION}

Vertebrate fossils and ichnofossils have also been collected in the Adamantina Formation, and they comprise reptile bones, coprolites as well as egg nests. The coprolites are known from several outcrops of the Adamantina Formation and are attributed to turtles and sauropod dinosaurs (Souto, 2003). The egg nests are interpreted as produced by crocodylomorphs (Ribeiro et al., 2004) and they occur in the same locality (Fazenda São José, municipality of General Salgado) of the Taenidium specimens described here. 


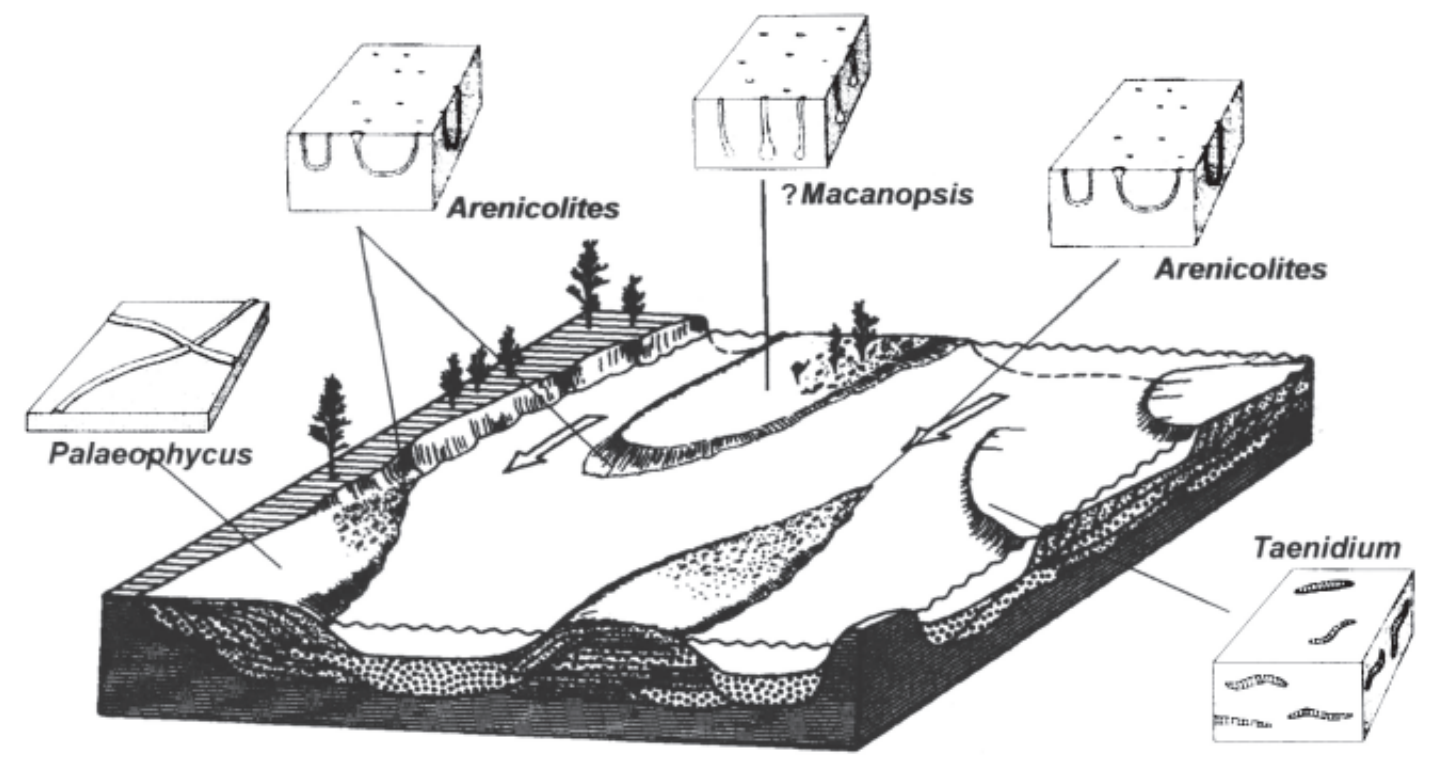

Figure 9. Trace fossil distribution in the alluvial plain sediments of Bauru Basin, Adamantina Formation.

\section{DISCUSSION}

In the continental environments, the bioturbation can be produced by several groups of invertebrate organisms, including nematodes, annelids, bivalves, gastropods and arthropods. Through their tracks and excavations, vertebrates are also able to rework the sedimentary deposits.

There is usually a large variety of ichnofossils in continental sediments, an aspect also observed by other authors in the analysis of non-marine ichnocoenoses (Ratcliffe \& Fagerstrom, 1980; Fitzgerald \& Barrett, 1986; D’Alessandro et al., 1987; Genise et al., 2000). The trace fossils described by D'Alessandro et al. (1987) in the meandering and braided stream deposits of the Duchesne River Formation (Eocene, Uinta Basin - U.S.A) are restricted to few invertebrate ichnogenera and rhizoliths. These were interpreted as endostratal traces, mainly preserved in floodplain sediments, unaltered or partially modified by soil development. As observed by Ratcliffe \& Fagerstrom (1980) in Holocene floodplain sediments, the biogenic activity of insects and arachnids are generally abundant locally, producing structures similar to the ichnogenus Macanopsis, that are also found in the Cretaceous sediments of Bauru Basin.

Throughout the Upper Cretaceous, due to the persistence of a hot climate and to surrounding topographic heights, there was a progressive increase in aridity in the Bauru Basin. This allowed the establishment of alluvial plains, braided rivers and small temporary ponds (Mezzalira, 1980; Campanha et al., 1992, Etchebehere et al., 1999; Goldberg \& Garcia, 2000). The invertebrate ichnofossils of the Adamantina Formation were collected in fine-grained sandstones, in the context of floodplain and channel-bar deposits (Figure 9). Some ichnogenera (Taenidium and Palaeophycus) reflect the activity of terrestrial and aquatic invertebrates through feeding and locomotion in the substrate. Arenicolites is a dwelling structure, while Macanopsis is a nesting trace. The trace fossils occur in sediments interpreted as deposited during sudden floods on alluvial plains under a dry and hot climate. Associated or in nearby correlated stratigraphic levels there are plant root traces, a great amount of crocodylomorph eggs and eggshells, that are indicative of a nesting area exposed for a long period of time.

The identification of a specific ichnofacies occurrence in the Adamantina Formation is a difficult task. Arenicolites is rare in the Scoyenia and Mermia Ichnofacies, but common in the Arenicolites Ichnofacies (sensu Bromley \& Asgaard, 1991; Bromley, 1996), and it occurs in the marine Skolithos, Cruziana and Glossifungites Ichnofacies. At present three ichnofacies are recognized in continental environments, the Coprinisphaera, Scoyenia and Mermia Ichnofacies. The Coprinisphaera Ichnofacies is characterized by a moderate to relatively high ichnodiversity with breeding structures of insects as bees, ants and beetles. Meniscate tubes, mammal burrows, and rhizoliths are also found. It comprises ecosystems of terrestrial herbaceous communities with paleosols developed in a wide range of depositional environments, such as alluvial plains, desiccated floodplains and vegetated aeolian deposits (Genise et al., 2000). The Scoyenia Ichnofacies comprises the transition from a terrestrial to a subaqueous setting, containing vertebrate tracks and invertebrate burrows such as Scoyenia, Beaconites, and Taenidium (Pemberton et al., 1992). The ichnofacies is characterized by horizontal and small burrows, related to feeding activities, as well as trackways and vertical cylindrical burrows. The Mermia Ichnofacies was proposed by Buatois \& Mángano (1995) for permanently subaqueous, lacustrine environments where ichnofossils such as Mermia, Helminthopsis, Cochlichnus, Planolites, Lockeia and Gordia can be found. 
The frequent occurrence of numerous specimens of Taenidium, Arenicolites and Palaeophycus in the sandstones of the Adamantina Formation, and their association with vertebrate coprolites and egg nests, suggest the establishment of the Scoyenia Ichnofacies in these floodplain deposits.

\section{CONCLUSIONS}

The Cretaceous invertebrate ichnofauna of the Adamantina Formation is composed of Arenicolites isp., ?Macanopsis isp., Palaeophycus herberti and Taenidium barretti. Plant root traces, vertebrate bones, coprolites and egg nests are also found associated with these ichnofossils. Their frequent occurrence in distinct stratigraphic levels of the Adamantina Formation fine-grained sandstones, interpreted as exposed channel-bars and floodplain areas of braided rivers, suggest the establishment of the Ichnofacies Scoyenia.

\section{ACKNOWLEDGMENTS}

Thanks are due to John E. Pollard and R. Goldring for a first critical review of the manuscript. To Andrew K. Rindsberg for the information concerning to tracemakers. The drawings presented in this paper were prepared by Luiz A. S. Ferro (UFRJ). We thank the financial support for the research provided by the Instituto Virtual de Paleontologia/Fundação Carlos Chagas Filho de Amparo à Pesquisa do Estado do Rio de Janeiro (FAPERJ), Conselho Nacional de Desenvolvimento Científico e Tecnológico (grants 300571/2003-8 and 301240/ 2003-5) and Fundação Universitária José Bonifácio (FUJBUFRJ).

\section{REFERENCES}

Batezelli, A.; Perinotto, J.A.J.; Etchebehere, M.L.C.; Fulfaro, V.J. \& Saad, A.R. 1999. Redefinição litoestratigráfica da unidade Araçatuba e da sua extensão regional na bacia Bauru, Estado de São Paulo, Brasil. In: SIMPÓSIO SOBRE O CRETÁCEO DO BRASIL, 5, 1999. Boletim, Serra Negra, UNESP, p. 195-200.

Bertini, R.J. 1993. Paleobiologia do Grupo Bauru, Cretáceo Superior continental da bacia do Paraná, com ênfase em sua fauna de amniotas. Programa de Pós-Graduação em Geologia, Universidade Federal do Rio de Janeiro, Tese de Doutorado, 397 p.

Binney, E.W. 1852. On some trails and holes found in rocks of the carboniferous strata, with remarks on the Microconchus carbonarius. Manchester Literary and Philosophical Society, Memoirs and Proceedings, 10(6):181-201.

Bown, T.M. 1982. Ichnofossils and rhizoliths of the nearshore fluvial Jebel Qatrani Formation (Oligocene), Fayum Province, Egypt. Palaeogeography, Palaeoclimatology, Palaeoecology, 40:255-309.

Bown, T.M. \& Kraus, M.J. 1983. Ichnofossils of the alluvial Willwood Formation (Lower Eocene), Bighorn Basin, Northwestern Wyoming, U.S.A. Palaeogeography, Palaeoclimatology, Palaeoecology, 43:95-128.

Bracken, B. \& Picard, M.D. 1984. Trace fossils from Cretaceous/ Tertiary North Horn Formation in central Utah. Journal of Paleontology, 58:477-487.

Bradshaw, M.A. 1981. Paeoenvironmental in terpretations and systematics of Devonian trace fossils from the Taylor Group (lower Beacon Supergroup), Antarctica. New Zealand Journal of Geology and Geophysics, 24:615-652.

Bromley, R.G. 1996. Trace fossils: biology, taphonomy and applications. $2^{\mathrm{a}}$ ed., London, Chapman and Hall, $361 \mathrm{p}$.

Bromley, R.G. \& Asgaard, U. 1991. Ichnofacies: a mixture of taphofacies and biofacies. Lethaia, 24:153-163.

Bromley, R. \& Asgaard, U. 1979. Triassic freshwater ichnocenoses from Carlsberg Fjord, East Greenland. Palaeogeography, Palaeoclimatology, Palaeoecology, 28:39-80.

Buatois, L.A. \& Mángano, M.G. 1993. Trace fossils from a Carboniferous turbiditic lake: implications for the recognition of additional nonmarine ichnofacies. Ichnos, 2:237-258.

Buatois, L.A. \& Mángano, M.G. 1995. The paleoenvironmental and paleoecological significance of the Mermia ichnofacies: an archetypical subaqueous nonmarine trace fossil assemblage. Ichnos, 4:151-161.

Buatois, L.A.; Mángano, M.G. \& Aceñolaza, F.G. 2002. Trazas fósiles. $1^{\text {a }}$ ed., Trelew, Museo Paleontológico Egidio Feruglio, $382 \mathrm{p}$.

Campanha, V.A.; Etchebehere, M.L.C.; Saad, A.R. \& Fulfaro, V.J.1992. O significado paleogeográfico das novas ocorrências fossilíferas do Grupo Bauru na região do Triângulo Mineiro, MG. In: SIMPÓSIO SOBRE AS BACIAS CRETÁCICAS BRASILEIRAS, 2, 1992. Resumos Expandidos, Rio Claro, UNESP, p. 151-152.

Carvalho, I.S. 1989. Icnocenoses continentais: bacias de Sousa, Uiraúna-Brejo das Freiras e Mangabeira. Programa de PósGraduação em Geologia, Universidade Federal do Rio de Janeiro, Dissertação de Mestrado, 167 p.

Castro, J.C.; Dias-Brito, D.; Musacchio, E.A.; Suarez, J.; Maranhão, M.S.A.S. \& Rodrigues, R. 1999. Arcabouço estratigráfico do Grupo Bauru no oeste Paulista. In: SIMPÓSIO SOBRE O CRETÁCEO DO BRASIL, 5, 1999. Boletim, Serra Negra, UNESP, p. 509-515.

D’Alessandro, A. \& Bromley, R.G. 1987. Meniscate trace fossils and the Muensteria-Taenidium problem. Palaeontology, 30(4):743-763.

D’Alessandro, A.; Ekdale, A.A. \& Picard, M.D. 1987. Trace fossils in fluvial deposits of the Duchesne River Formation (Eocene), Uinta Basin, Utah. Palaeogeography, Palaeoclimatology, Palaeoecology, 61(3/4):285-301.

Dias-Brito, D.; Musacchio, E.A.; Castro, J.C.; Maranhão, M.S.A.S.; Suárez, J.M. \& Rodrigues, R. 2001. Grupo Bauru: uma unidade continental do Cretáceo no Brasil - concepções baseadas em dados mocropaleontógicos, isotópicos e estratigráficos. Revue de Paléobiologie, 20(1):245-304.

Etchebehere, M.L.C.; Fulfaro, V.J.; Saad, A.R. \& Perinotto, J.A.J. 1999. O significado estratigráfico da calcretização por água subterrânea no Triângulo Mineiro, Sudoeste do Estado de Minas Gerais, Brasil. In: SIMPÓSIO SOBRE O CRETÁCEO DO BRASIL, 5, 1999. Boletim, Serra Negra, UNESP, p. 427-431.

Fernandes, A.C.S. 2001. A paleoicnofauna brasileira de artrópodes: estado atual de seu conhecimento. Acta Geologica Leopoldensia, 24(52/53):359-372.

Fernandes, A.C.S. \& Carvalho, I.S. 2001. Icnofósseis de invertebrados da bacia de Sousa (Estado da Paraíba, Brasil): a localidade de Serrote do Letreiro. Crato, DNPM, URCA e SBP, Coleção Chapada do Araripe n ${ }^{\circ}$ 1, p. 147-155.

Fernandes, A.C.S.; Carvalho, I.S. \& Netto, R.G. 1990. Icnofósseis de invertebrados da Formação Botucatu, São Paulo (Brasil). Anais da Academia Brasileira de Ciências, 62(1):45-49. 
Fernandes, A.C.S.; Borghi, L.; Carvalho, I.S. \& Abreu, C.J. 2002. Guia dos icnofósseis de invertebrados do Brasil. $1^{\text {a }}$ ed., Rio de Janeiro, Interciência, 260 p.

Fernandes, A.C.S.; Carvalho, I.S.; Srivastava, N.K.; Henriques, M.H.P. \& Reis, R.P.B.P. 1998. Icnofósseis da Bacia do Araripe (Formação Arajara - Cretácico), Brasil. Comunicações do Instituto Geológico e Mineiro, 84(1):A197-A200.

Fernandes, L.A. \& Coimbra, A.M. 1996. A bacia Bauru (Cretáceo Superior, Brasil). Anais da Academia Brasileira de Ciências, 68:195-205.

Fernandes, L.A. \& Coimbra, A.M. 1999. Paleocorrentes da parte oriental da Bacia Bauru (KS, Brasil). In: SIMPÓSIO SOBRE O CRETÁCEO DO BRASIL, 5, 1999. Boletim, Serra Negra, UNESP, p. 51-57.

Fillion, D. \& Pickerill, R.K. 1990. Ichnology of the Upper Cambrian? to Lower Ordovician Bell Island and Wabana groups of eastern Newfoundland, Canada. Palaeontographica Canadiana, 7:1119.

Fitzgerald, P.G. \& Barret, P.J. 1986. Skolithos in a Permian braided river deposit, Southern Victoria Land, Antarctica. Palaeogeography, Palaeoclimatology, Palaeoecology, 52:237247.

Fulfaro, V.J.; Perinotto, J.A.J. \& Barcelos, J.H. 1994. A margem goiana do Grupo Bauru: implicações na litoestratigrafia e paleogeografia. In: SIMPÓSIO SOBRE O CRETÁCEO DO BRASIL, 3, 1994. Boletim, Rio Claro, UNESP, p. 81-84.

Gandini, R.; Paz, C.P.; Netto, R.G. \& Vargas, M. 2004. First record of the Scoyenia Ichnofacies in the Ladinian-Eonorian (Triassic) sedimentary succession of the Paraná Basin, Southern Brazil. In: ICHNIA 2004 FIRST INTERNATIONAL CONGRESS ON ICHNOLOGY, 2004. Abstract Book, Trelew, Museo Paleontológico Egidio Feruglio, p. 36.

Genise, J.F.; Mángano, G., Buatois, L.A.; Laza, J.H. \& Verde, M. 2000. Insect trace fossil associations in paleosols: the Coprinisphaera ichnofacies. Palaios, 15:49-64.

Goldring, R. 1962. The trace fossils of the Baggy Beds (Upper Devonian of north Devon, England. Paläontologische Zeitschrift, 36:232-251.

Goldring, R. \& Pollard, J.E. 1995. A re-evaluation of Ophiomorpha burrows in the Wealden Group (Lower Cretaceous) of southern England. Cretaceous Research, 16:665-680.

Goldberg, K. \& Garcia, A.J.V. 2000. Palaeobiogeography of the Bauru Group, a dinosaur-bearing Cretaceous unit, northeastern Paraná Basin, Brazil. Cretaceous Research, 21:241-254.

Hall, J. 1847. Paleontology of New York. Volume I. Containing descriptions of the organic remains of the Lower Division of the New York System, (equivalent of the Lower Silurian rocks of Europe). Albany, C. Van Benthuysen, 338 p.

Hall, J. 1852. Paleontology of New York. Volume II. Containing descriptions of the organic remains of the Lower Middle Division of the New York System, (equivalent in part to the Middle Silurian rocks of Europe). Albany, C. Van Benthuysen, $362 \mathrm{p}$.

Häntzschel, W. 1975. Trace fossils and problematica. In: C. Teichert (ed.) Treatise in Invertebrate Paleontology, Part W, Miscellanea, Supplement I. Geological Society of America and University of Kansas Press, Boulder, Colorado and Lawrence, Kansas, p. W1-W269.

Hasiotis, S.T.; Aslan, A. \& Bown, T.M. 1993. Origin, architecture, and paleoecology of the Early Eocene continental ichnofossil Scaphichnium hamatum, integration of ichnology and paleopedology. Ichnos, 3:1-9.
Heer, O. 1876-1877. Flora fossilis Helvetiae. Die vorweltliche Flora der Schweiz. Zürich, J. Wüster \& Co., 182 p.

Keighley, D.G. \& Pickerill, R.K. 1995. The ichnotaxa Palaeophycus and Planolites: historical perspectives and recommendations. Ichnos, 3:301-309.

Macsotay, O. 1967. Huellas problemáticas y su valor paleoecológico en Venezuela. Geos, 16:7-79.

Mezzalira, S. 1980. Aspectos paleoecológicos da Formação Bauru. In: MESA REDONDA SOBRE A FORMAÇÃO BAURU NO ESTADO DE SÃO PAULO E REGIÕES ADJACENTES. Sociedade Brasileira de Geologia, Núcleo de São Paulo, Publicação Especial, 7:1-14.

Miller, S.A. \& Dyer, C.B. 1878. Contributions to paleontology, No. 2. Cincinnati, private publ., $11 \mathrm{p}$.

Musacchio, E.A. 2000. Biostratigraphy and biogeography of Cretaceous charophytes from South America. Cretaceous Research, 21:211-220.

Netto, R.G. 1989. Paleoicnologia das seqüências eólicas sotopostas à Formação Botucatu no Rio Grande do Sul. Acta Geologica Leopoldensia, 28:31-44.

Netto, R.G. 2000. Paleoicnologia do Rio Grande do Sul. In: M. Holz \& L.F. De Ros (eds.). Paleontologia do Rio Grande do Sul. Porto Alegre, Centro de Investigação do Gonduana e Universidade Federal do Rio Grande do Sul, p. 25-43.

Netto, R.G.; Nowatzki, C.H. \& Faccini, U.F. 1994. Icnofósseis das unidades triássicas da fronteira Brasil-Uruguay. In: CONGRESSO BRASILEIRO DE GEOLOGIA, 38, 1994. Boletim de Resumos Expandidos, Balneário Camboriú, SBG, v. 3, p. $217-$ 218.

Pemberton, S.G. \& Frey, R.W. 1982. Trace fossil nomenclature and the Planolites-Palaeophycus dilemma. Journal of Paleontology, 56(4):843-881.

Pemberton, S.G.; MacEachern, J. \& Frey, R.W. 1992. Trace fossils facies models. Environmental and allostratigraphic significance. In: R.G. Walker \& N.P. James (eds.) Facies models - response to sea level changes. Geological Association of Canada, p. $47-$ 72.

Ratcliffe, B.C. \& Fagerstrom, J.A. 1980. Invertebrate lebensspuren of Holocene floodplains: their morphology, origin and paleoecological significance. Journal of Paleontology, 54(3):614630.

Ribeiro, C.M.M. \& Ribeiro, L.C.B. 1999. Um ovo de dinossauro em sucessões fluviais da Formação Marília (Cretáceo Superior), em Peirópolis (Uberaba, Minas Gerais). In: SIMPÓSIO DE GEOLOGIA DO SUDESTE, 6, 1999. Boletim de Resumos, São Pedro, p. 76.

Ribeiro, C.M.M.; Carvalho, I.S.; Arruda, J.T. \& Campos, A.C.A. 2004. Crocodylomorph egg nests from the Adamantina Formation (Bauru Basin, Late Cretaceous), Brazil. In: INTERNATIONAL CONGRESS ON ICHNOLOGY, 1, 2004. Abstract Book, Trelew, Museo Paleontológico Egídio Feruglio, p. 68 .

Rindsberg, A.K. \& Kopaska-Merkel, D.C. 2005. Treptichnus and Arenicolites from the Steven C. Minkin Paleozoic footprint site (Langsettian, Alabama, USA). In: Rindsberg, A.K. \& Kopaska-Merkel, D.C. (eds.) Pennsylvanian Footprints in the Black Warrior Basin of Alabama. Alabama Paleontological Society Monograph no. 1, p. 121-141.

Salter, J.W. 1856. On fossil remains in the Cambrian rocks of the Longmynd and north Wales. Quaterly Journal of the Geological Society of London, 12:246-252.

Salter, J.W. 1857. On annelide-burrows and surface-markings from 
the Cambrian rocks of the Longmynd. No. 2. Geological Society of London Quaterly Journal, 13:199-206.

Saporta, G. de 1872. Paléontologie française ou description des fosiles de la France (commencée par Alcide d'Orbigny et continuée par une réunion de paléontologistes sous la direction d'un comité special). Série 2. Végétaux. Plantes jurassiques, 110. Paris, G. Masson, 432 p.

Soares, P.C.; Landim, P.M.B.; Fulfaro, V.J. \& Sobreiro Neto, A.F. 1980. Ensaio de caracterização estratigráfica do Cretáceo no
Estado de São Paulo: Grupo Bauru. Revista Brasileira de Geociências, 10:177-185.

Souto, P.R.F. 2003. Coprólitos do Cretáceo do Brasil. Programa de Pós-Graduação em Geologia, Universidade Federal do Rio de Janeiro, Tese de Doutorado, $237 \mathrm{p}$.

Uchman, A. 1995. Taxonomy and palaeoecology of flysch trace fossils: the Marnoso-arenacea Formation and associated facies (Miocene, Northern Apennines, Italy). Beringeria, 15:3-83.

Received in June 2005; accepted in June 2006. 